\title{
Properties of Non-NMDA Excitatory Amino Acid-Activated Channels in Isolated Retinal Horizontal Cells
}

\author{
Eric M. Lasater \\ University of Utah, School of Medicine, Department of Physiology and Department of Ophthalmology, Salt Lake City, \\ Utah 84108
}

\begin{abstract}
The excitatory amino acid glutamate is believed to be the neurotransmitter used by some photoreceptors in the teleost retina. Past studies have shown that exogenous glutamate, and its analogs, are capable of affecting second-order retinal neurons in a manner consistent with the action of a photoreceptor transmitter. In an effort to characterize the properties of retinal glutamate channels on second-order neurons, non-NMDA excitatory amino acid-activated channels were studied in single horizontal cells isolated from the retina of the white bass.

Using patch-clamp techniques single glutamate, kainate, and quisqualate channels were recorded. Two categories of channels were observed. The first was labeled slow-channels. Single-channel conductances and open times for this channel showed a range of values, but the average for channels activated by glutamate was $12 \mathrm{pS}$ and $5.6 \mathrm{msec}$; quisqualate, $8.5 \mathrm{pS}$ and $8.8 \mathrm{msec}$; and kainate, $8.5 \mathrm{pS}$ and 4.5 msec. Openings of slow-channels elicited by the agonists tended to occur in bursts with a mean burst length of $\mathbf{3 8}$ msec. The bursts were punctuated by numerous, brief closings. The second channel category was termed fast channels. The agents glutamate, quisqualate, and kainate all activated channels in this category with open times of 1-2 msec and 2 prominent conductances in the range of about 10 and 20-30 pS. Activity of the fast channels tended to be noisy and no bursting behavior was observed.
\end{abstract}

Glutamate has long been recognized as a major neurotransmitter in the CNS, where it plays a prominent role, with aspartate, as the primary excitatory neurotransmitter (Mayer and Westbrook, 1987). More recently, glutamate has been shown to be an equally important neurotransmitter in the vertebrate retina. Autoradiographic labeling demonstrated glutamate uptake by certain photoreceptors in the goldfish retina (Marc and Lam, 1981). Physiologically, glutamate was shown to depolarize horizontal cells in the intact retina and block their light responses (Murakami et al., 1972; Wu and Dowling, 1978). In mudpuppy retina, Slaughter and Miller (1981) demonstrated that the glu-

\footnotetext{
Received Aug. 21, 1989; revised Nov. 10, 1989; accepted Dec. 13, 1989.

I would like to thank Dr. Gordon Fain for comments and suggestions on the work and Drs. John Dowling and Andy Knapp for reading and commenting on the manuscript. This work was supported by NIH grant EY05972, an unrestricted grant to the Department of Ophthalmology from Fight for Sight, Inc. (FFS), and a Research Manpower Award from FFS to the author.

Correspondence should be addressed to Eric M. I-asater, University of Utah, School of Medicine, Department of Physiology, 410 Chipeta Way, Salt Lake City, UT 84108.

Copyright $(1990$ Society for Neuroscience $0270-6474 / 90 / 051654-10 \$ 02.00 / 0$
}

tamate analog 2-amino-4-phosphonobutyrate (APB) selectively blocked the light responses of on-bipolar cells. Nawy and Copenhagen (1987) found 2 types of L-glutamate receptors on the mixed rod-cone on-bipolar of goldfish. One was blocked by APB and was associated with rod input, while the other was APB insensitive and associated with cone input. In addition, isolated horizontal cells from carp (Lasater and Dowling, 1982), skate (Lasater et al., 1984), goldfish (Ishida et al., 1984), and catfish (Hals et al., 1986) have been shown to be depolarized by exogenous applications of L-glutamate. Taken together, these studies support the role of glutamate as an excitatory photoreceptor neurotransmitter.

The mechanism underlying glutamate's action on retinal horizontal cells has only recently been investigated. These studies uscd noisc analysis to provide information on the fundamental properties of horizontal cell excitatory amino acid-gated channels. Ishida and Neyton (1985) studied the actions of glutamate and its agonists kainate and quisqualate on isolated goldfish horizontal cells. They found that these agents gated a channel with 2 time constants $\tau_{1}=5 \mathrm{msec}, \tau_{2}=1 \mathrm{msec}$, and an elementary conductance of 2-3 pS. In a similar study, O'Dell and Christensen (1989) observed the effects of NMDA, kainate, and quisqualate on isolated catfish horizontal cells. These agents showed $\tau$ 's of around 1-2 msec and unitary conductances of about 6,4 , and 3-8 pS, respectively. It was interesting that they were also able to show that isolated catfish horizontal cells possessed an NMDA receptor. At the present time there is some debate as to the existence of NMDA receptors on teleost horizontal cells. Work in the intact retina has demonstrated responses to applied aspartate (Murakami et al., 1972; Wu and Dowling, 1978) in some instances and not others (Rowe and Ruddock, 1982). In other isolated teleost horizontal cell preparations, an NMDA receptor has not been observed (Lasater and Dowling, 1982; Ishida et al., 1984; Lasater et al., 1984; Ishida and Neyton, 1985).

The present studies were undertaken in an effort to analyze the single-channel properties of non-NMDA excitatory amino acid-gated channels in horizontal cells. In the goldfish and catfish work cited above, the time constants of the channel gating in the 2 studies were similar. However, the unitary conductances in catfish seemed to be about twice the size of those estimated in goldfish. The experiments reported on here investigated the unitary properties of excitatory amino acid-gated channels found in the horizontal cells of white bass. It was found that in bass, the elementary conductances were more like catfish than goldfish. In addition, based on single-channel open times, 2 types of channels were found. 


\section{Materials and Methods}

Cell isolations. The isolation procedure used to obtain single retinal neurons has been described in detail elsewhere (Dowling et al., 1985). In brief, dark-adapted eyes were removed from white bass (Roccus chrysops), the retinas isolated from the pigment epithelium and placed in Leibowitz's (L-15) medium (GIBCO) containing the proteolytic enzyme papain $(15-20 \mathrm{U} / \mathrm{ml}$ ) (Worthington Biochemicals). The retinas were incubated in the L-15/papain solution for 45-60 min followed by several washes in L-15. The retinas were then triturated through a Pasteur pipette, and isolated cells were plated out into $35 \mathrm{~mm}$ tissue culture grade petri dishes containing L-1 5 . Cells were used following $1-$ $14 \mathrm{~d}$ in culture.

Recording solutions. Most recordings were made in the on-cell configuration (Hamill et al., 1981). For unknown reasons this proved to be the most successful approach for obtaining single glutamate channels in horizontal cells. A drawback to this strategy is that the membrane potential of the cell is not known with any accuracy, and as a result, the patch potential is never known with certainty. One way to get around this is to introduce a second electrode (either a fine-tipped intracellular electrode or a patch electrode for whole-cell recording) into the cell in order to control the cell's membrane potential. This was done here on several occasions. However, a more straightforward approach that was used was to depolarize the membrane potential of the cell to a known potential by bathing the cell in a high-potassium Ringer's solution. To do this, the cells were bathed in Ringer's containing (in mM) $132 \mathrm{KCl}$ or K-gluconate, $2.1 \mathrm{CaCl}_{2}, 1.2 \mathrm{MgCl}_{2}, 0.4 \mathrm{KH}_{2} \mathrm{PO}_{4}, 1.2 \mathrm{NaHCO}_{3}, 10$ glucose, and 8.4 HEPES buffered to $\mathrm{pH} 7.5$ with $\mathrm{KOH}$. Often the solution also contained 20 TEA and 10 4-AP. Cells bathed in this solution had resting potentials, as measured with single-electrode current-clamp, of $0 \mathrm{mV}$ or within a few $\mathrm{mV}$ of 0 . Under these conditions, the solution used to fill the patch-pipettes was identical to the above solution except that the $\mathrm{KCl}$ or K-gluconate was replaced with $\mathrm{NaCl}$ (normal Ringer's). The electrode also contained the agonists, either glutamate, quisqualate, or kainate (Sigma Chemical Co.; Research Biochemicals Inc.).

On some occasions outside-out patches were recorded from. For these, the extracellular Ringer's was similar to the above solution with 130 $150 \mathrm{NaCl}, 2.9 \mathrm{KCl}, 2.1 \mathrm{CaCl}_{2}, 1.2 \mathrm{MgCl}_{2}, 0.4 \mathrm{KH}_{2} \mathrm{PO}_{4}, 1.2 \mathrm{NaHCO}_{3}$, 10 glucose, and 8.4 HEPES and sometimes 20 TEA and $104-A P$. The intracellular solution which filled the pipette contained (in $\mathrm{mM}$ ) 120 $\mathrm{CsCl}, 1 \mathrm{CaCl}_{2}, 2 \mathrm{MgCl}_{2}, 11$ EGTA, $1 \mathrm{Mg}$-ATP, $10 \mathrm{HEPES}$ buffered to pH 7.4 with $\mathrm{NaOH}$. A second intracellular solution sometimes used contained $145 \mathrm{CsCl}, 4 \mathrm{NaCl}, 0.5 \mathrm{CaCl}_{2}, 5$ EGTA, 8.4 HEPES buffered to $\mathrm{pH} 7.4$ with $\mathrm{CsOH}$. The free calcium concentration in these solutions was estimated to be buffered to $8.3 \times 10^{-9}$ and $9.3 \times 10^{-9}$, respectively. No differences in the results were seen between the 2 intracellular solutions. Glutamate agonists were superfused over the outside-out patches via pressure from small-bore pipettes located close to the cell under study.

Electrophysiology. Pipettes were manufactured from borosilicate glass with either a Kopf (David Kopf Instruments) or Narishige (Medical Systems Corp.) vertical pipette puller. The electrodes were then heatpolished and coated with Sylgard (Dow Corning Corp.). When filled with Ringer's solution and tested in Ringer's, the electrodes had DC resistances of $3-6 \mathrm{~m} \Omega$. All recordings were carried out using an Axopatch-1B patch-clamp amplifier (Axon Instruments, Inc.). Potentials given are referred to the intracellular side of the membrane. Data were filtered at 1 or $2 \mathrm{~K}(-3 \mathrm{~dB}$ freq.) (Ascher and Nowak, 1988a) and on a few occasions $5 \mathrm{~K}$ and stored on video tape using a PCM adaptor (A. $\mathrm{R}$. Vetter Co.). Digitization of the data (5-10 times the $-3 \mathrm{~dB}$ freq.) and subsequent analysis was carried out using Axon Instruments' pClamp suite of programs. An idealized record of channel openings was produced by first determining the maximum amplitude of events in a given recording. A threshold was then set such that an opening to $50 \%$ of this value or greater caused the program to select the event. The event was then manually accepted and added to the event list or rejected. The analysis of fast channels (see below) was often complicated by noisy baselines. To establish a baseline, the peak-to-peak noise level in a segment of data lacking openings was estimated and the baseline set at $50 \%$ of this value. Open times and single-channel amplitudes were binned and displayed as a histogram. The open times were fit by the sum of one or more exponentials, while the amplitude histograms were fit by the sum of one or more Gaussians. Closed times were not investigated in detail here. In addition, the patches seldom contained more than one channel, so no correction factors were necessary for overlapping channel openings.

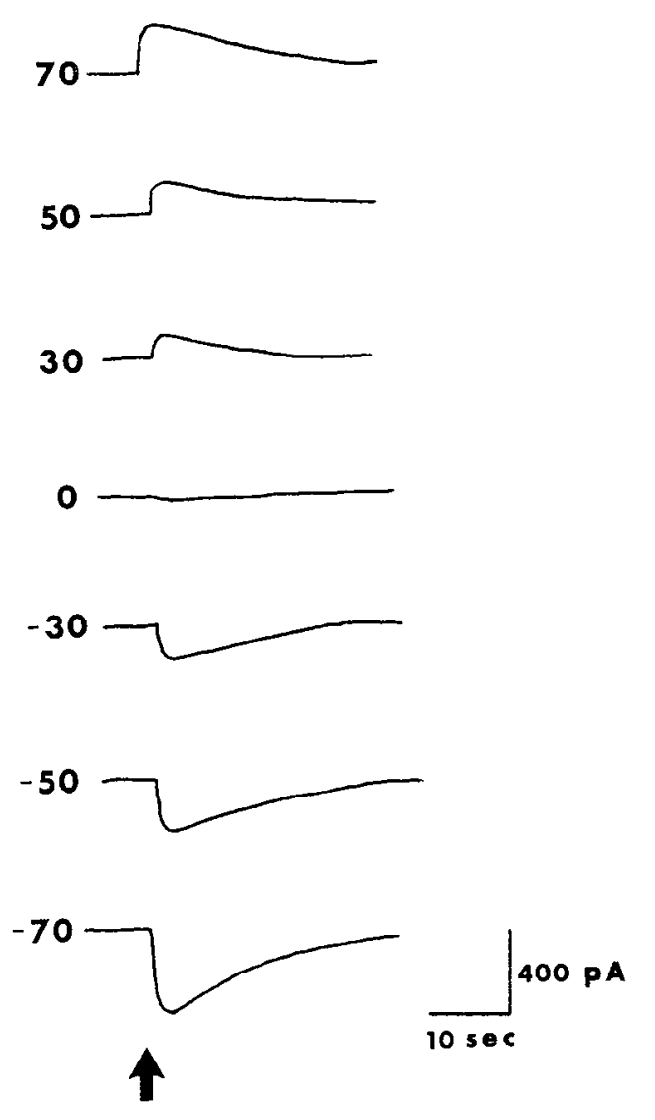

Figure 1. The reversal potential of kainate responses in an $\mathrm{H} 2$ horizontal cell. The cell was whole-cell voltage-clamped to the membrane potential indicated to the left of each trace. At each holding potential, $10 \mu \mathrm{M}$ kainate was applied at the point in time marked by the arrow from a pressure-ejection pipette located close to the cell. At hyperpolarized potentials an inward current was elicited by kainate application. The response decreased as the cell was held more depolarized and reversed around $0 \mathrm{mV}$.

\section{Results}

In goldfish (Ishida et al., 1984) and catfish (Hals et al., 1986), glutamate and its analogs kainate and quisqualate, when applied to a horizontal cell at a holding potential of $-70 \mathrm{mV}$, produces a large inward current. The current reverses at about $0 \mathrm{mV}$ and seems to be carried by cations. This appears to be the case also for white bass horizontal cells. Figure 1 illustrates the wholecell response of a bass horizontal cell to the application of kainate at various holding potentials. At $-70 \mathrm{mV}$ there is a large inward current. As the cell is held more positive, the current diminishes and reverses around 0 . A similar type of response was seen for glutamate and quisqualate. Responses to exogenous NMDA $(200 \mu \mathrm{M})$ were never seen, even in Ringer's containing no $\mathrm{Mg}^{2+}$ and $1 \mu \mathrm{M}$ glycine.

The single-channel current of glutamate and its analogs was also seen to reverse at around $0 \mathrm{mV}$. Figure $2 A$ shows the singlechannel responses to quisqualate and kainate at several holding potentials. At a holding potential of $-70 \mathrm{mV}$, large events can be seen. The events get smaller as the potential across the patch is brought closer to $0 \mathrm{mV}$. The events reverse at around $0 \mathrm{mV}$. Figure $2 B$ is a current-voltage plot of the single quisqualateactivated channels shown in Figurc $2 A$. To estimate the singlechannel conductance, a regression line was calculated and drawn through the data points with a slope of $8.3 \mathrm{pS}$. 
A

QU1S

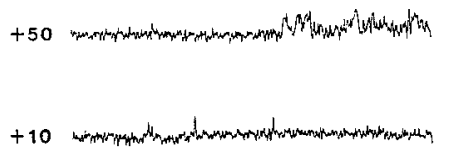

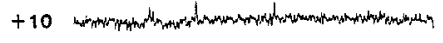

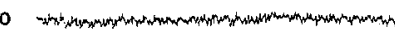

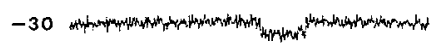

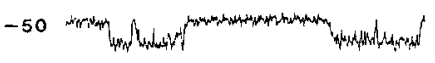

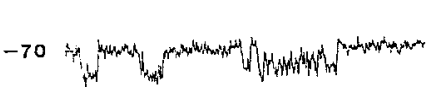

KA
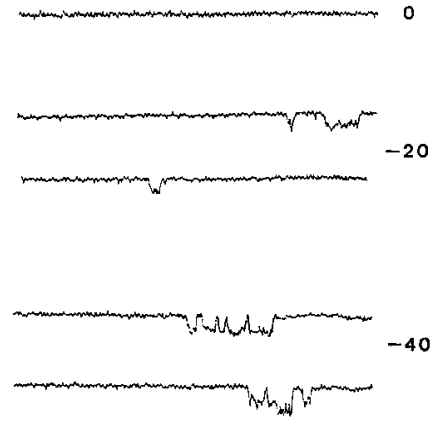

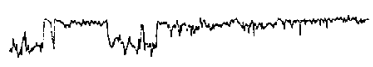

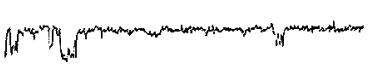

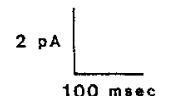

B

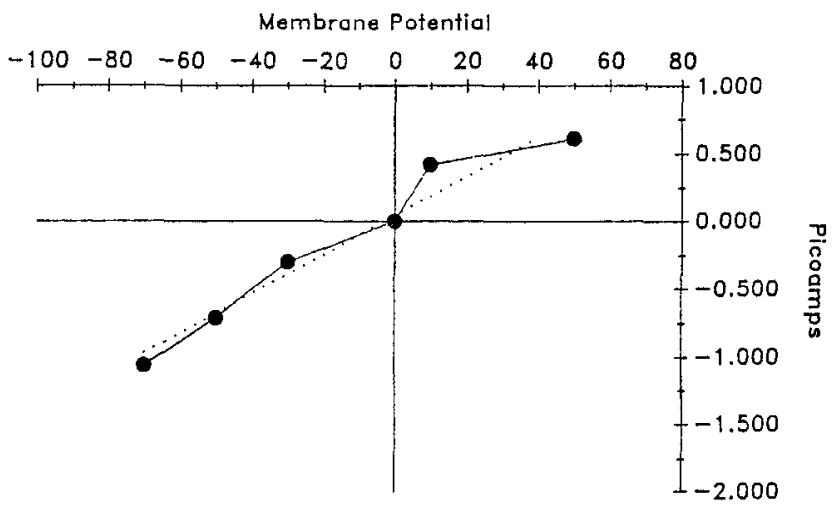

Single-Channel Conductance (quis)

Figure 2. Reversal of non-NMDA single channels. On-cell patches were used to obtain single channels $(A)$ elicited by quisqualate $(l e f t)$ and kainate $($ right $)$. The cells were bathed in high-potassium Ringer's and the pipettes contained normal Ringer's with the agonists at the following concentrations: quisqualate, $50 \mu \mathrm{M}$; kainate, $20 \mu \mathrm{M}$. The holding potential is beside each set of traces. As with the whole-cell currents, the single-channel openings were seen to reverse at around $0 \mathrm{mV} . B, I-V$ relationship for the quisqualate channel.

A

Glutamate

Control

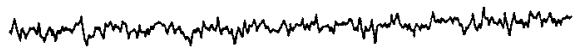

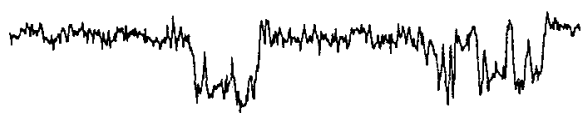

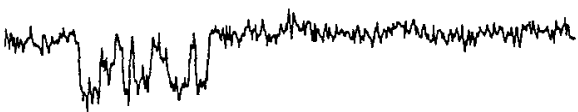

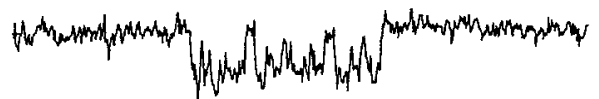

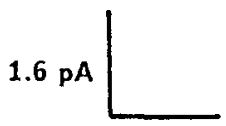

$40 \mathrm{msec}$
B

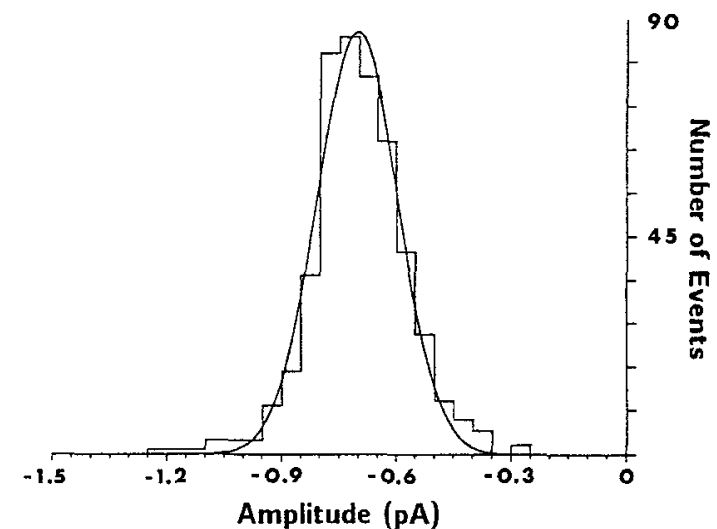

C

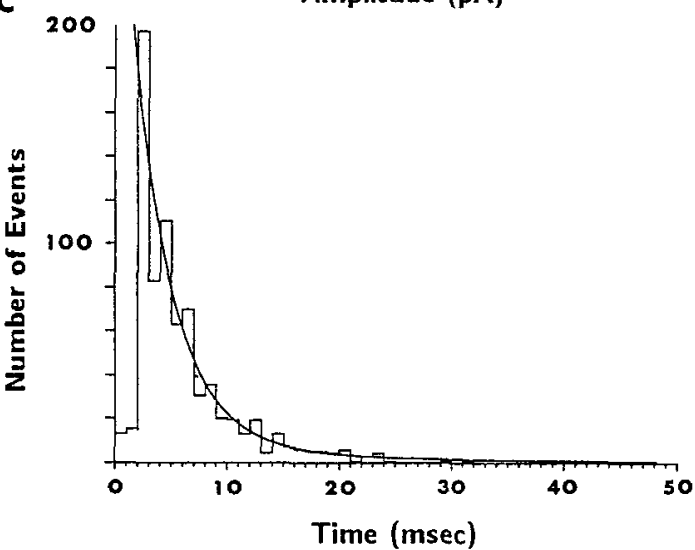

Figure 3. Single-channel openings evoked by glutamate. $A$, Records containing a single glutamate channel which has been termed a slow channel (see text). Openings were recorded in an on-cell patch in which the membrane potential was $-70 \mathrm{mV}$. The cell was bathed in high-potassium Ringer's and the electrode contained $100 \mu \mathrm{M}$ glutamate. The trace labeled control is a record of the mcmbrane current at $0 \mathrm{mV}$. The 3 traces under the control trace were obtained when the potential across the membrane was brought to $-70 \mathrm{mV}$. The data was filtered at $1 \mathrm{~K}(-3 \mathrm{~dB})$. The traces as displayed in this figure and those figures that follow are noncontiguous. $B$, The amplitude histogram was fit by one Gaussian with a mean of $0.7 \mathrm{pA}$. $C$, The open time histogram was fit by the sum of 2 exponentials with a $\tau_{1}=3.5 \mathrm{msec}$ and $\tau_{2}=21.7 \mathrm{msec}$. 

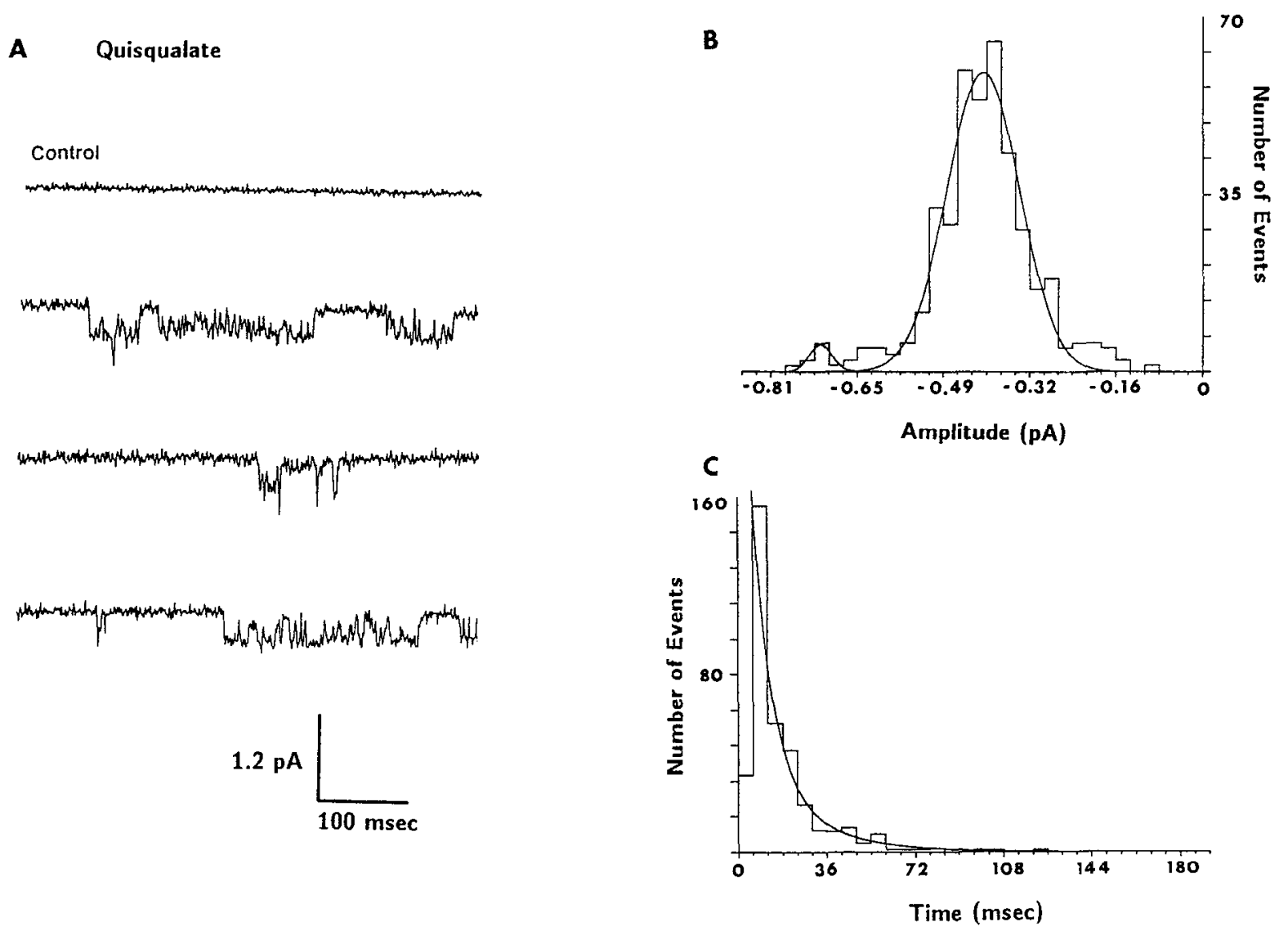

Figure 4. Single channel activated by quisqualate. The cell was bathed in high-potassium Ringer's, and the recording pipette contained normal Ringer's and $20 \mu \mathrm{M}$ quisqualate. $A$, On-cell recording of channel openings filtered at $500 \mathrm{~K}$. The Control trace was obtained when the membrane potential was $0 \mathrm{mV}$, and the 3 lower traccs when the pipette potential was adjusted such that the membrane potential of the patch was $-70 \mathrm{mV}$. Several long bursts can be seen during which there occurs a great deal of flicker. During the flicker, the channel likely closes very rapidly; however, in many cases only incomplete closures are observed. This may be due to the effects of filtering the record or possibly the channel closes incompletely. $B$, The amplitude histogram shows at least 2 open levels fit by 2 Gaussians. The major level had a mean at $0.41 \mathrm{pA}$ and the other at $0.72 \mathrm{pA}$. $C$, Open time histogram was fit by the sum of 2 exponentials $\left(\tau_{1}=7.95 \mathrm{msec}\right.$ and $\left.\tau_{2}=24.32 \mathrm{msec}\right)$.

\section{Non-NMDA channels}

Non-NMDA excitatory amino acid-gated channels in bass were similar to non-NMDA-gated channels recorded from CNS neurons (Ascher and Nowak, 1988b; Cull-Candy et al., 1988). Figure $3 A$ illustrates a glutamate-activated channel recorded from an on-cell patch. For the purposes of this report, the type of channel shown in Figure 3 is termed a "slow channel." Openings to one level can be seen with some transitions to what might be a higher level. In addition, flicker activity can be seen during the openings. A Gaussian was fitted to the peak of the amplitude histogram (Fig. 3B) with a mean conductance of $10 \mathrm{pS}$. The open time histogram (Fig. 3C) was fitted with the sum of 2 cxponentials with $\tau_{1}=3.5 \mathrm{msec}$ and $\tau_{2}=21.7$. In other cclls, glutamate generally opened slow channels to one main conductance level of around 10-12 pS, although less frequent transitions to other conductance levels were seen. In one outside-out patch, glutamate was seen to open 2 channels which had conductances of 6 and $14 \mathrm{pS}$, respectively. For 4 patches ( 1 outsideout, 3 on-cell), the average glutamate conductance was (pS \pm SD) $12.3 \pm 1.6 \mathrm{pS}$, with an average open time of (msec \pm SD) $5.6 \pm 1.6 \mathrm{msec}$.

A quisqualate-gated channel is illustrated in Figure $4 A$. These records were obtained from an on-cell patch. At $-70 \mathrm{mV}$, longduration openings could be seen with a great deal of flicker activity present. The channel opened predominantly to a single level of $0.41 \mathrm{pA}(6 \mathrm{pS})$ (Fig. $4 B$ ). Sometimes brief transitions to a higher level $(0.72 \mathrm{pA}$ or $10 \mathrm{pS})$ could be detected, but these were relatively rare as seen in the amplitude histogram (Fig. $4 B$ ). The mean open time histogram (Fig. 4C) of this channel was fit by the sum of 2 exponentials with $\tau_{1}=7.9 \mathrm{msec}$ and $\tau_{2}$ $=24.3 \mathrm{msec}$. The average of 3 patches (all on-cell) activated by quisqualate had a conductance of $8.5 \pm 3.2 \mathrm{pS}$ and an open time of $\tau_{1}=8.8 \pm 2.2 \mathrm{msec}$.

Figure $5 A$ illustrates a channel from an on-cell patch activated by kainate. Kainate-activated channels were very similar to the quisqualate channcls. When the membrane was hypcrpolarized, long openings with a large amount of flicker activity were seen. Openings to 2 levels were observed, but the openings to the higher conductance level were rare. The amplitude histogram (Fig. $5 B$ ) was fit by the sum of 2 Gaussians, with means at 0.70 $\mathrm{pA}(10 \mathrm{pS})$ and $1.2 \mathrm{pA}(17 \mathrm{pS})$ in this case. The open time histogram (Fig. $5 \mathrm{C}$ ) was fit by the sum of 2 exponentials with $\tau_{1}=4.6 \mathrm{msec}$ and $\tau_{2}=24 \mathrm{msec}$. When data from 4 patches (all on-cell) were averaged, the mean conductance to kainate was $8.5 \pm 2.9 \mathrm{pS}$ and the mean open time was $4.5 \pm 1.3 \mathrm{msec}$. 

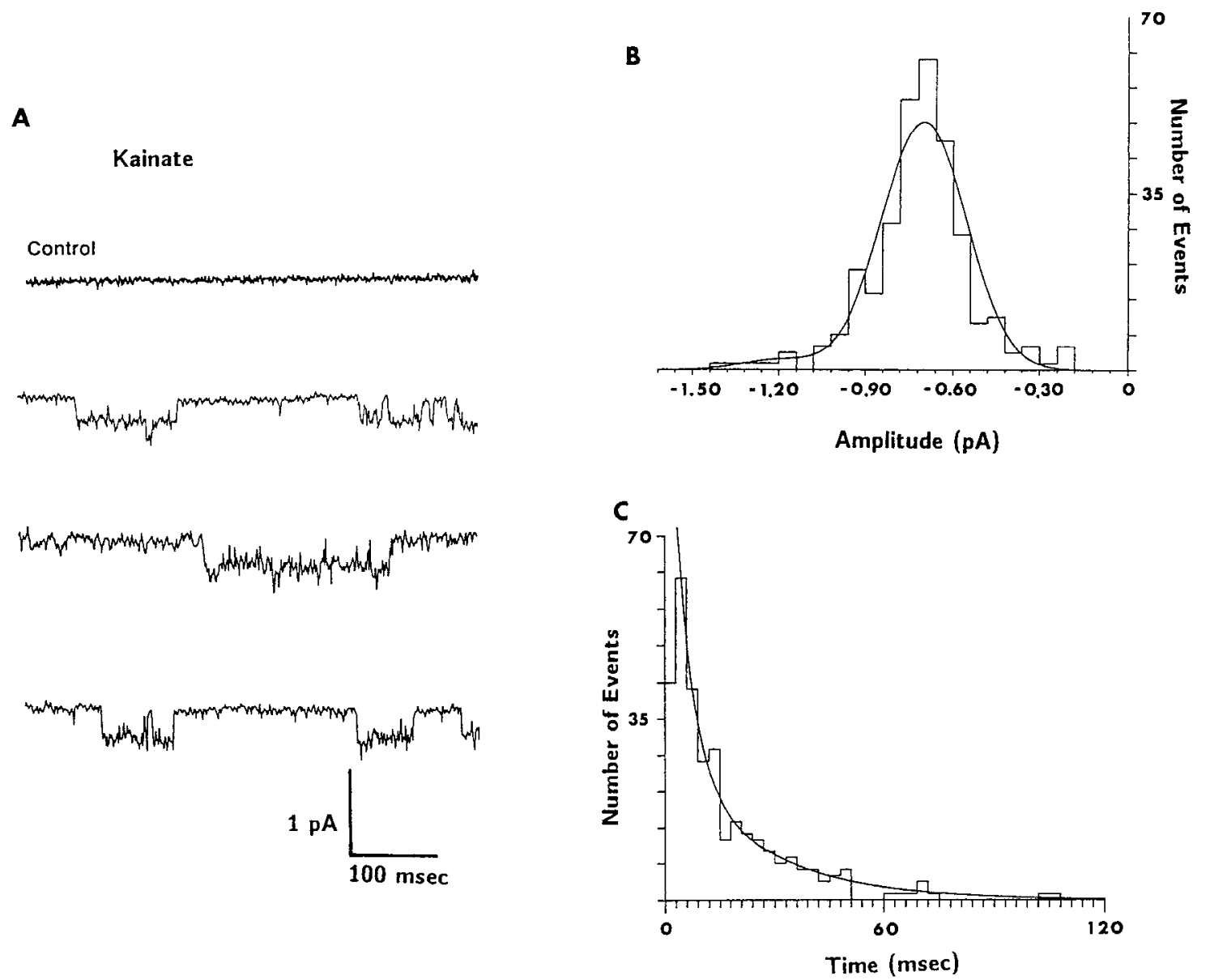

Figure 5. Single channel activated by kainate. $A$, Records obtained from an on-cell patch. The cell was bathed in high-potassium Ringer's, and the electrode contained normal Ringer's and $50 \mu \mathrm{M}$ kainate. In the upper trace (Control), the membrane potential was $0 \mathrm{mV}$. The pipette potential was adjusted such that the membrane potential of the patch was $-70 \mathrm{mV}$ in the 3 lower traces. Similar to quisqualate, kainate evoked long-duration openings with a great deal of opening and closing activity. The data were filtered at $2 \mathrm{~K}$. $B$, Open time histogram was fit by 2 Gaussians. The major open level was to a mean of $0.70 \mathrm{pA}$, but there was a small component at the $1.19 \mathrm{pA}$ level. $C$, Open time histogram was fit by the sum of 2 exponentials with $\tau_{1}=4.6 \mathrm{msec}$ and $\tau_{2}=24 \mathrm{msec}$.

\section{Fast activity channels}

Not all horizontal cell non-NMDA-gated channels behaved as those described above. Often very fast, "noisy" channel activity (Ascher and Nowak, 1988b; Llano et al., 1988) was observed. These channels are termed "fast channels" here to differentiate them from the previously described "slow channels." Figure 6 illustrates fast-channel activity that was elicited by glutamate. The records were obtained from an outside-out patch when the membrane potential was hyperpolarized to $-40 \mathrm{mV}$ in this case. Identical activity was seen in on-cell patches as well. In the absence of glutamate, the current record was like that labeled control. When glutamate was applied as a continuous stream from a nearby pressure-ejection pipette, the overall membrane noise increased, and very brief, spike-like openings were observed (Fig. 64, lower traces). Longer-duration openings were sometimes observed interspersed among the fast activity, and several can be seen in Figure 6. Inspection of the raw data suggested that openings to 2 different levels occurred. This was borne out in the amplitude histogram (Fig. 6B). The sum of 2 Gaussians was fit to the histogram with mean amplitudes of $0.62 \mathrm{pA}(15 \mathrm{pS})$ and $1.30 \mathrm{pA}(32 \mathrm{pS})$. Openings to the smaller level predominated. A single-exponential curve was fit to the open time histogram with a $\tau=1.03$ msec. For 6 patches $(2$ outside-out, 4 on-cell) that showed this fast activity to glutamate, the mean open time $( \pm \mathrm{SD})$ was $1.4 \pm 0.3 \mathrm{msec}$. In just about all cases, 2 prominent conductance levels were seen and their mean conductances $( \pm \mathrm{SD})$ were $12.2 \pm 3.0$ and $30.3 \pm$ 4.0 pS. Both high- and low-conductance events were usually present in a given patch.

Similar results were obtained with kainate and quisqualate. For 4 patches ( 1 outside-out, 3 on-cell) exposed to kainate that possessed fast activity, the mean open time was $1.8 \pm 0.5 \mathrm{msec}$, and the mean conductances were $6.9 \pm 2.7$ and $13.4 \pm 6.0 \mathrm{pS}$. Fast channels activated by quisqualate in 3 patches (all on-cell) had a mean open time of $1.2 \pm 0.2 \mathrm{msec}$ and mean conductances of $9.9 \pm 2.2$ and $22.8 \pm 1.6 \mathrm{pS}$. Fast-channels were more prevalent than the slow-channels, with about $65 \%$ of the channels recorded being the fast type. The distribution of the channel types was not investigated in detail here. However, on several cells from which multiple patches were obtained, only one channel type was found on a given cell.

The fast channel activated by glutamate bore a resemblance to NMDA channels recorded in the presence of magnesium (Nowak et al., 1984; Ascher and Nowak, 1988b). To determine if these were NMDA (or non-NMDA)-activated channels that 
A

Glutamate
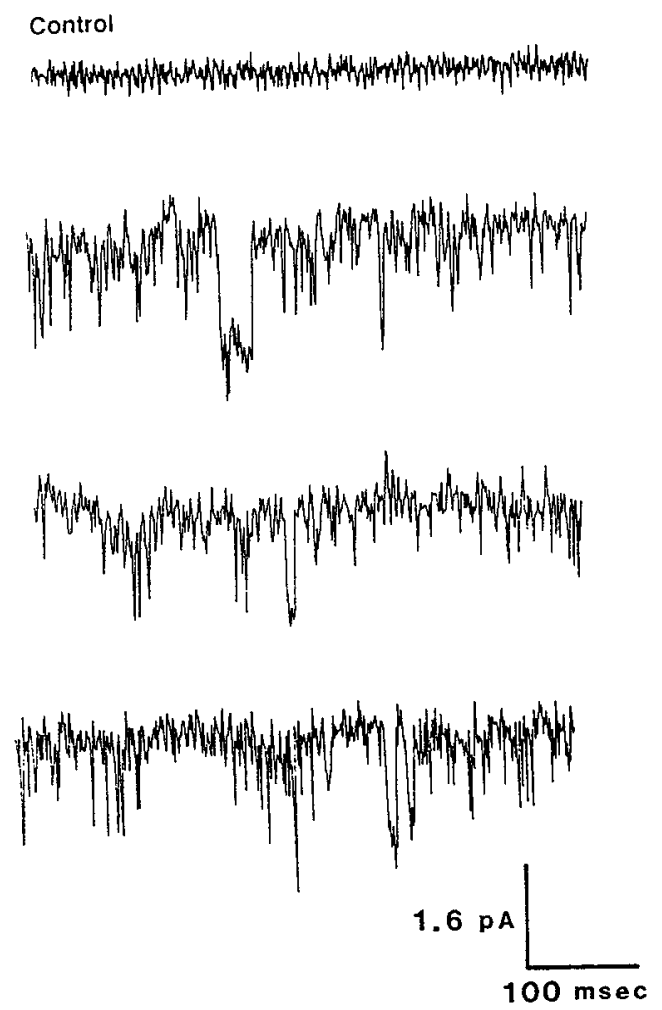
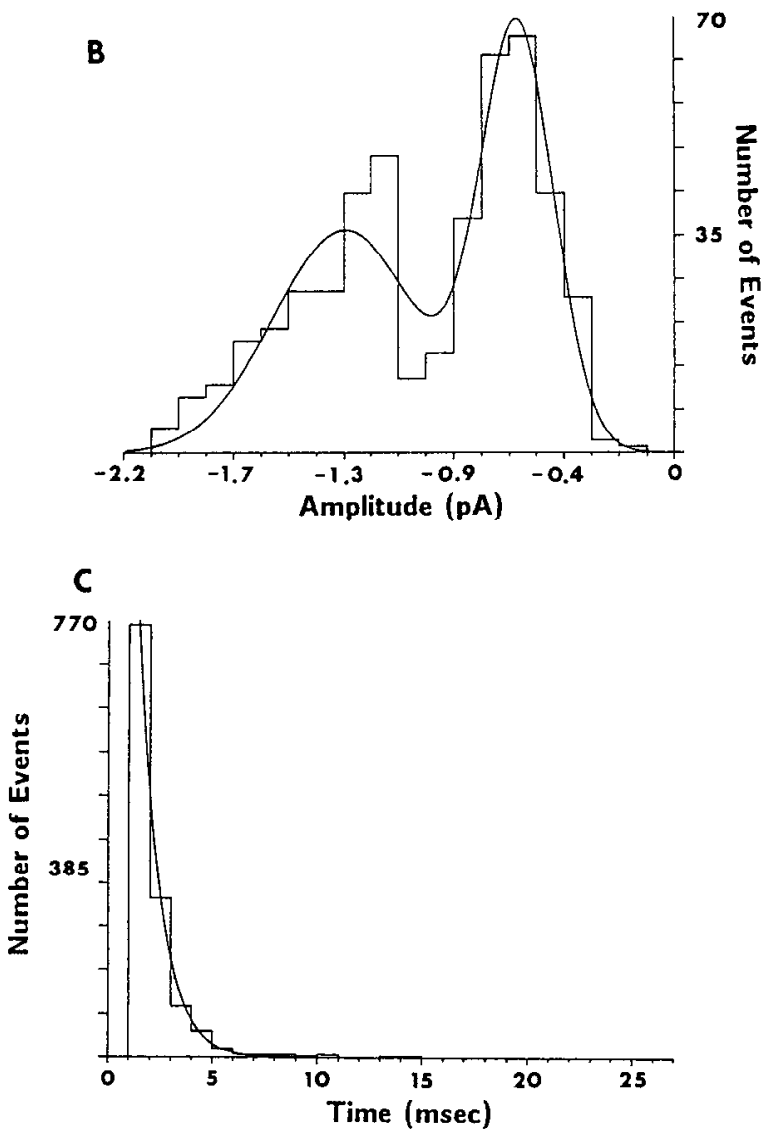

Figure 6. Fast channel activated by glutamate. Recordings $(A)$ were made from an outside-out patch that was held at $-40 \mathrm{mV}$ in $0 \mathrm{Mg}{ }^{2+} \mathrm{Ringer}^{\prime}$. The record marked control was obtained prior to the superfusion of $100 \mu \mathrm{M}$ glutamate over the patch. The records were filtered at $2 \mathrm{~K}$, but similar results were obtained at a filter setting of $5 \mathrm{~K}$. Two amplitudes of openings were seen in the amplitude histogram $(B)$. The histogram was fit by 2 Gaussians with means at 0.62 and $1.30 \mathrm{pA}$. Unlike the slow channels illustrated in the previous figures, the open time histogram for the fast channels was fit best by one exponential $(\tau=1.03 \mathrm{msec})$, even though there were infrequent long-duration openings. The records of $A$ were chosen to illustrate some examples of the longer-duration openings and are not indicative of their frequency of occurrence since the records are noncontiguous. The amplitude histogram has been truncated so some of the longer-duration openings do not appear on it. Quisqualate and kainate activated similar fast channels in bass horizontal cells.

were undergoing voltage-dependent block by magnesium, some experiments were carried out in $0 \mathrm{Mg}^{2+}$ Ringer's. The experiment of Figure 6 was such an experiment. Recordings made in $0 \mathrm{Mg}^{2+}$ Ringer's were identical to those from normal Ringer's. In addition, experiments on fast quisqualate and kainate channels in low $\mathrm{Mg}^{2+}$ were no different from those obtained in the presence of $\mathrm{Mg}^{2+}$. Thus, it is unlikely that the activity of the channels can be ascribed to a blocking action of magnesium in the bathing media.

\section{Bursting and flicker activity}

Often the opening of a horizontal cell, non-NMDA slow-channel occurred as a relatively long burst with a great deal of noise and many brief closures. The mean burst length elicited by all 3 agonists was $38 \mathrm{msec}$ (measured when closures $<1 \mathrm{msec}$ were ignored). During these bursts, transitions to intermediate open levels were sometimes seen. Examples can be seen in Figures 4 and 5. Figure 7 illustrates in detail examples of long bursts seen while recording activity due to each of the different agonists. There was not much difference in activity during a burst between the different agonists. Most notably, glutamate tended to pro- duce the largest amount of noise and flicker, although this was not examined quantitatively. These long bursts of activity, broken up by rapid openings and closings, in the slow channels probably accounts for the 2 time constants seen in some cells when fitting the open time histograms for the 3 agonists.

\section{Multiple conductance levels}

Multiple conductances were apparent for the slow channels gated by all 3 agonists, although more than one conductance level was not always seen in the amplitude histograms from every patch. The fast channels all showed at least 2 conductance levels, but because the openings were so brief, it was difficult to say if there were discrete openings to the different levels or if there were transitions from one level to another. Examples of slowchannel multiple conductance levels can be seen in Figure 8 for a kainate-activated channel. Two primary conductance levels were seen, one of $12 \mathrm{pS}$ and the other of $21 \mathrm{pS}$. The openings to the $12 \mathrm{pS}$ level were primarily of long duration. The openings to the $21 \mathrm{pS}$ level occurred most often during an opening to the $12 \mathrm{pS}$ level and were very short, spike-like transients which infrequently overshot $21 \mathrm{pS}$ to a third level of $31 \mathrm{pS}$. These 
Kainate

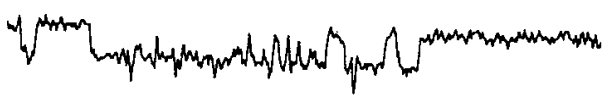

Quisqualate

Figure 7. Examples of long-duration openings elicited by non-NMDA excitatory amino acid agonists. Openings in each case were obtained from on-cell patches. The cells were bathed in highpotassium Ringer's and the pipette potential adjusted to give a $-70 \mathrm{mV}$ membrane potential. The concentrations of agonist in the pipette were (in $\mu \mathrm{M})$ kainate, 10; quisqualate, 20; and glutamate, 100 . The kainate and quisqualate records were filtered at $500 \mathrm{~K}$ and the glutamate record at $1 \mathrm{~K}$. See text for details.

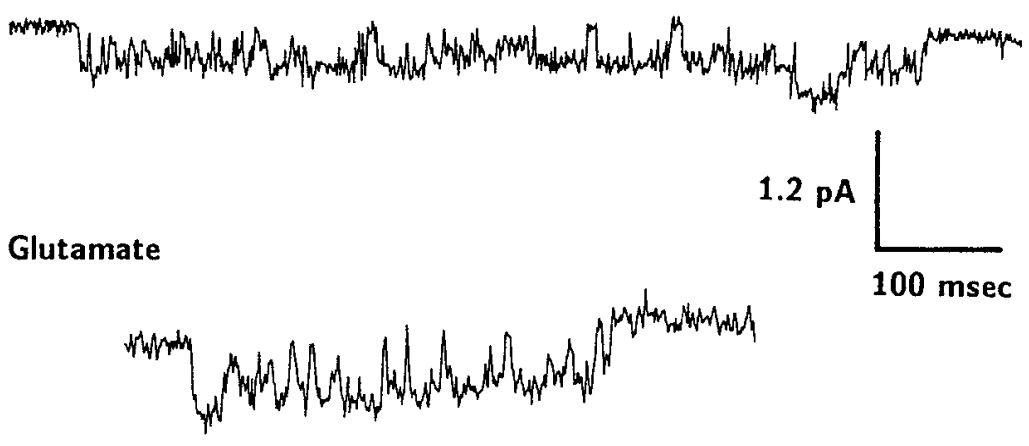

\section{KA}
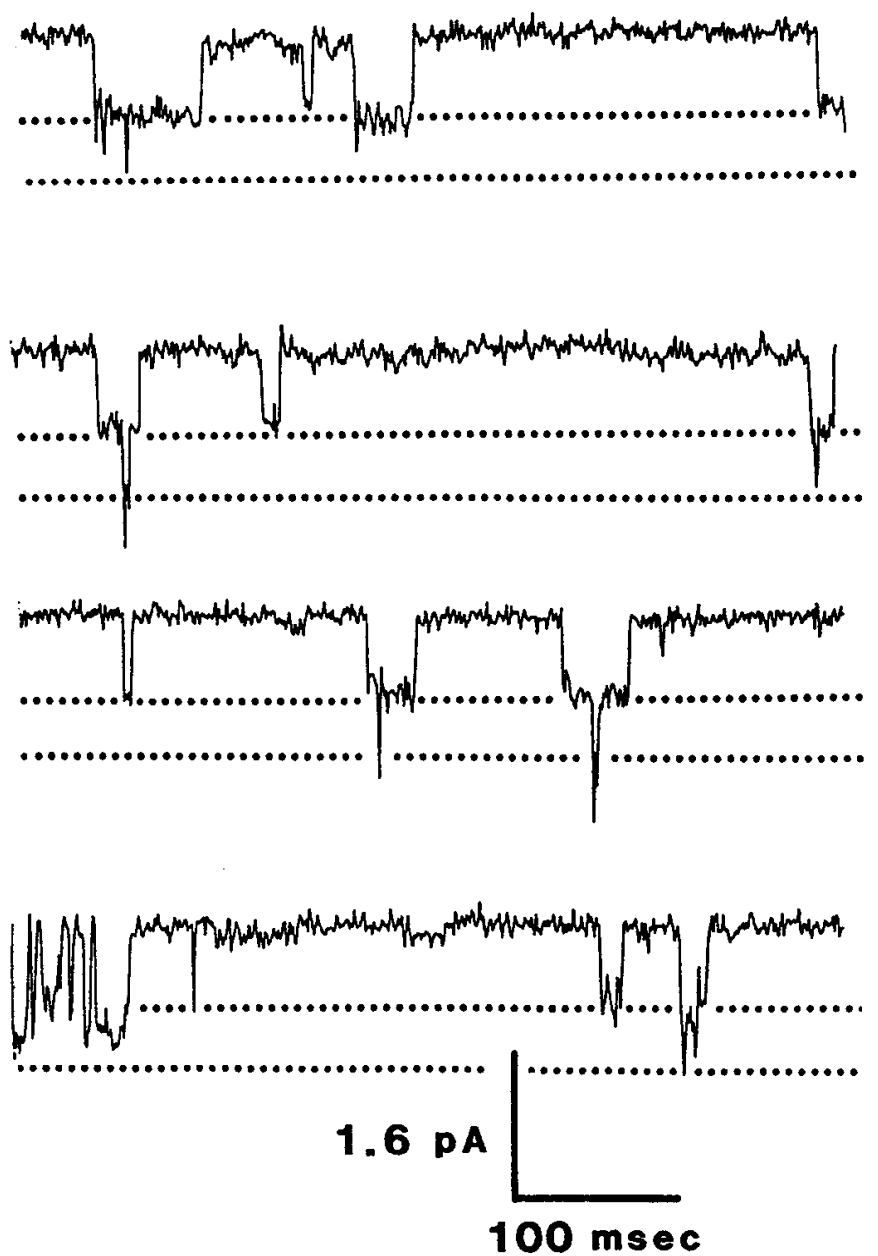

Figure 8. Examples of multiple conductance levels elicited by $10 \mu \mathrm{M}$ kainate in an on-cell patch. Recording conditions were similar to previous on-cell recordings. Two prominent conductance levels were observed at 12 and $21 \mathrm{pS}$. Infrequently, openings to $31 \mathrm{pS}$ were also seen (second and third traces). Data filtered at $1 \mathrm{~K}$. See text for details. rapid transient openings to a higher conductance level from a long-duration opening were characteristic of openings to subconductance states in horizontal cell glutamate channels. Because in this instance the value of the higher level is almost twice that of the lower level, one might argue that multiple channels were being activated. However, this is unlikely to be the case. The openings to the higher level were much less frequent and were always very brief compared with the openings to the lower level. If 2 similar channels were being activated, one might expect the open times and the frequency of opening to be very similar. This was not the case.

Multiple conductance states were observed in only about $30 \%$ of the slow channels recorded, and what was usually observed were transitions from the primary level to a higher level, very similar to that illustrated in Figure 8. The higher conductance level was usually on the order of 15-20 pA.

\section{Discussion}

Single non-NMDA excitatory neurotransmitter-gated channels were investigated in horizontal cells isolated from the retina of the white bass. It was an arduous task gathering data on these channels in that activity was observed in only about $15 \%$ of the patches recorded from. In addition it was easier to obtain data with on-cell rather than excised patches. The reason for this is unknown; however, it suggests that the channel density is rather low.

To test this assumption, channel density can be estimated assuming a maximum glutamate current of $1 \mathrm{nA}$ in a whole cell and a cell surface area of $5,000 \mu \mathrm{m}^{2}$. For a single glutamate channel the current generated $(I)$ is $I=V g$, where $V$ is the driving force and $g$ is the single-channel conductance. For a driving force of $70 \mathrm{mV}$ and a conductance of $12 \mathrm{pS}, I=\left(70 \times 10^{-3}\right)$ $\left(12 \times 10^{-12}\right)=0.84 \times 10^{-12} \mathrm{~A}$. The number of open channels $(N)$ needed to produce a $1 \mathrm{nA}$ current $\left(I_{\max }\right)$ is $N=I_{\max } / I=1$ $\times 10^{-9} / 0.84 \times 10^{-12}=1190$ channels. This means that there are 1190 channels $/ 5000 \mu \mathrm{m}^{2}$ or 1 channel every $4.2 \mu \mathrm{m}^{2}$ or 0.24 channels $/ \mu \mathrm{m}^{2}$. This is a relatively low density compared with chick spinal cord neurons, where the density was estimated to be $20-640$ channels $/ \mu \mathrm{m}^{2}$ (Trussell and Fischbach, 1989). It is likely that in vivo the horizontal cell glutamate channel density is higher. Photoreceptor contact with horizontal cells is made 
by fine horizontal cell processes which invaginate the receptor terminal (Dowling, 1987). These fine processes, which are likely to possess a large number of glutamate receptors, are probably lost during the isolation procedure.

The whole-cell current of bass horizontal ccll clicited by nonNMDA agonists was similar to those described in catfish (Hals et al., 1986) and goldfish (Ishida et al., 1984) in that at the resting potential $(-70 \mathrm{mV})$ of the cells a large inward current was evoked. This current reversed at around $0 \mathrm{mV}$. Similarly, single-channel openings also reversed around $0 \mathrm{mV}$. Ion-substitution experiments in catfish and goldfish indicated that glutamate and its analogs opened channels that were permeable to cations, primarily sodium. It is likely that non-NMDA-gated channels in bass retina have a similar ionic specificity.

\section{Glutamate-gated channels}

The agonist glutamate gated a slow channel with a mean conductance for the channel of about $12 \mathrm{pS}$. This conductance, while somewhat higher than that of kainate and quisqualate channels, was not significantly different from them. Thus, it is probable that the glutamate is activating kainate- and/or quisqualate-type channels and not a separate channel.

The magnitude of the conductance of glutamate-gated channels in horizontal cells is similar to that seen in other systems. Cull-Candy et al. (1988) found that in rat cerebellar cells glutamate activated small conductances in the range of 8 and 15 $\mathrm{pS}$ in addition to other large, probably NMDA-receptor-linked conductances. The small conductances most likely corresponded to those gated by kainate and quisqualate.

The mean open time of the slow glutamate channels was around 5-6 msec. Often, the open time histogram could be fit with 2 exponentials. The longer time constant was probably due to the bursting seen in the slow channels. That is, an overall long-duration opening would be punctuated with rapid openings and closings. On the other hand, the fast channels had a mean open time of 1-2 msec. This is similar to the open time of channels described in catfish horizontal cells (O'Dell and Christensen, 1989).

\section{Kainate-and quisqualate-gated channels}

Kainate gated a slow-channel that was similar to the glutamategated channel. It had a mean open time of around 7-8 $\mathrm{msec}$ and a mean single-channel conductance of about $7 \mathrm{pS}$. The channel conductance was not significantly different from glutamate or quisqualate channel conductance. Sometimes the open time histogram could be fit by 2 exponentials. Again, this was probably due to the bursting behavior of the channels. In 2 of 4 patches analyzed in detail, multiple conductance levels were observed. Bass kainate channels were similar to those described in CNS preparations. In mouse CNS neurons, kainate activated a channel with an open time of $2 \mathrm{msec}$ and conductances of 4 and $20 \mathrm{pS}$ (Ascher and Nowak, 1988a). In rat cerebellar cells, mean open times of 1 and $5 \mathrm{msec}$ were seen and among several conductance levels, one had a conductance of $8 \mathrm{pS}$, similar to what was seen here (Cull-Candy et al., 1988).

Quisqualate gated slow channels that had a mean open time of about $7 \mathrm{msec}$ and a mean conductance of around 8-9 $\mathrm{pS}$, similar to the 8-15 pS range seen in CNS neuron preparations (Ascher and Nowak, 1988b; Cull-Candy ct al., 1988). Two of four channels had open time histograms fit by 2 exponentials, indicative of the bursting behavior seen in the glutamate- and kainate-gated channels. In addition, 1 of 3 patches had an amplitude histogram indicating multiple conductance states.

\section{Fast channels}

The fast channels described here in bass horizontal cells are similar to channels gated by kainate in mouse CNS neurons (Ascher and Nowak, 1988a) and rat cerebellar and hippocampal neurons (Llano et al., 1988). In these cells, at $-60 \mathrm{mV}$ the major component of the noise power spectra had a time constant of around $1 \mathrm{msec}$. In addition, both large- and small-amplitude openings were observed, but only rarely were they seen together in the same patch. In bass, openings to the 2 different levels were often seen in the same patch $(n=8)$. However, in 5 other patches only one amplitude of opening was observed. In 4 of these 5 , only openings to the low-conductance level $(\approx 8-10 \mathrm{pS})$ were observed, while in 1 only openings to the high level $(\approx 30$ pS) were seen.

The origin of these fast, spiky openings is unclear. Several possibilities present themselves. First, they could be nothing more than artifacts arising from extraneous noise or seal breakdown. This is unlikely to be the case since such noise is usually distributed evenly about some mean value. This was not seen here. The second possibility exists that what was observed was the result of some type of agonist-induced desensitization of the receptor. This possibility cannot be ruled out altogether but nonetheless is also not very likely. Concanavalin A (Con A) has been shown to reduce or eliminate desensitization of excitatory amino acid receptors on catfish horizontal cells (O'Dell and Christensen, 1989). Two patches from bass horizontal cells were recorded from in the presence of Con $A$ (not illustrated), and openings in these patches were the fast, spiky openings seen in untreated patches. A third possibility is that these spiky openings are due to a $\mathrm{Mg}^{2+}$-induced rapid flickering of an NMDA channel gated by the agonists (Ascher and Nowak, 1988b). The experiments in $\mathrm{Mg}^{2+}$-free Ringer's dispelled this notion (Fig. 6). The most plausible explanation for the 2 types of kinetically different openings seen here is that there exists on bass horizontal cells 2 types of channels with different gating kinetics. One channel, the fast channel, opens and closes rapidly $(\tau=1-2 \mathrm{msec})$. In general, it conducts primarily at about $8-10 \mathrm{pS}$ but also conducts frequently at a higher level of 20-30 pS. The second channel, the slow channel, has a longer mean open time, $5-10 \mathrm{msec}$, and conducts primarily at around $9 \mathrm{pS}$. The notion of 2 channel types is borne out by the fact that Ishida and Neyton (1985) found their power spectra from excitatory amino acid-gated channels in goldfish could be fit with 2 Lorentzians with time constants of 1 and $5 \mathrm{msec}$. It is also intriguing that the slow channels resemble more closely those described in CNS neurons, while the fast channels are like those of catfish horizontal cells. The fast channels are currently under study in greater detail.

\section{Multiple conductance states}

Multiple conductance states were observed in channels activated by all 3 agonists. About one-third of the slow channels recorded exhibited conductances to primarily 2 levels, around 10 and 20 pS. Transitions from the lower conductance states to the higher ones were most often observed. These consisted primarily of relatively fast, brief transitions from the low conductance level to the higher one (Fig. 8). However, in all these cases, jumps directly to the higher conductance levels were also seen. In one unusual case, glutamate activated what appeared to be 2 separate channels of different conductances, 6 and $14 \mathrm{pS}$, in the same 
patch. The meaning of this is not clear but suggests a heterogeneous population of channels.

Most of the fast channels ( $75 \%$ ) opened to at least 2 conductance states. Because of the short open times of these channels, it was relatively difficult to characterize the various conductance levels. The conductance varied in the ranges of 5-15 and 20$35 \mathrm{pS}$. Transitions from one level to another were usually unresolvable but could on occasion be observed.

\section{Presence of NMDA channels}

The existence of NMDA-gated channels on fish horizontal cells is an enigma. Early work with intact retina showed that aspartate depolarized carp horizontal cells in a manner expected of the endogenous photoreceptor neurotransmitter (Murakami et al., 1972; Wu and Dowling, 1978). However, more recent studies particularly with isolated cells, argues against the presence of NMDA receptors on fish horizontal cells since aspartate and NMDA were without a depolarizing effect in these experiments (Lasater and Dowling, 1982; Rowe and Ruddock, 1982; Ariel et al., 1984, 1986; Ishida et al., 1984; Lasater et al., 1984; Ishida and Neyton, 1985). On the other hand, most recently, O'Dell and Christensen (1989) provide compelling evidence for the existence of NMDA receptors on catfish horizontal cells.

While the evidence is not overwhelming, data from the present work does not support the existence of NMDA receptors on bass horizontal cells. It is not likely that glutamate was opening an NMDA channel on bass cells like that described in CNS neurons for 2 reasons. First, in other systems, NMDA opens channels that have a primary conductance of 40-50 pS (Jahr and Stevens, 1987; Ascher et al., 1988; Cull-Candy ct al., 1988) and no conductances to that level were observed in horizontal cells, even in $0 \mathrm{Mg}^{2+}$ glycine-containing Ringer's. Second, the glutamate channels seen here were recorded in Ringer's containing magnesium, which would be expected to antagonize NMDA responses (Nowak et al., 1984). It is possible that glutamate is opening an NMDA channel with a small conductance, perhaps like that described in culfish (O'Dell and Christensen, 1989). Alternatively, it may be opening an NMDA channel to one of the infrequently observed subconductance levels of CNS systems (Ascher et al., 1988; Cull-Candy et al., 1988). Again, however, if this were the case, in these experiments $\mathrm{Mg}^{2+}$ would be expected to block the channels since O'Dell and Christensen found that $\mathrm{Mg}^{2+}$ blocked the catfish horizontal cell NMDA channel. In any case, if there is an NMDA channel activated by the agonists used here, it is very different from the channels described in the CNS. Interestingly, Allen et al. (1988) recently reported that trypsin inactivated NMDA receptors. Although unlikely, it is possible that the papain we use does something similar in that it alters an NMDA channel such that in bass it rarely conducts and then in only an attenuated manner.

\section{Receptor-channel complexes}

At present there is some question as to the relationship between excitatory amino acid receptors and the channels they gate. Based on work with hippocampal and cerebellar neurons, it has been proposed that the same molecule bears receptors to both NMDA and non-NMDA agonists and that the gating of the channel and the channel conductance is determined by the agonist bound (Jahr and Stevens, 1987; Cull-Candy and Usowicz, 1988). On the other hand, in their work on mouse CNS neurons Ascher and Nowak (1988a) felt that the best explanation of existing data was a model in which distinct receptor-channel complexes existed. Each complex was defined by a primary agonist and was capable of adopting multiple conductance states.

Currently no simple conclusions can be drawn in this regard for bass horizontal cells. The average conductance of bass kainate-gated channels is not significantly different from the average conductance of quisqualate-gated channels. Past work on horizontal cells favors the idea that in bass, kainate and quisqualate are binding to a common receptor site. Ishida and Neyton (1985) found that glutamate and quisqualate inhibited responses to kainate, and they proposed that the agonists were binding, for the most part, to a kainate receptor. Likewise, O'Dell and Christensen (1989) favor a common binding site mediating the responses to glutamate, kainate, and quisqualate in catfish horizontal cells, also based on competition studics. Howcver, their data suggest that the glutamate receptor that is being activated is of the quisqualate type. On-cell, single-channel studies do not easily allow an assessment of agonist interactions or agonist efficacy. Nonetheless, the present data are not incompatible with the notion of a single channel protein being gated by both quisqualate and kainate in bass horizontal cells. Whether this is a kainate or quisqualate receptor remains to be established.

\section{References}

Allen CN, Brady R, Swann J, Hori N, Carpenter DO (1988) N-MethylD-aspartate (NMDA) receptors are inactivated by trypsin. Brain Res 458:147-150.

Ariel M, Lasater EM, Mangel SC, Dowling JE (1984) On the sensitivity of $\mathrm{H} 1$ horizontal cells of the carp retina to glutamate, aspartate and their agonists. Brain Res 295:179-183.

Ariel M, Mangel SC, Dowling JE (1986) N-Methyl-D-aspartate acts as an antagonist of the photoreceptor transmitter in the carp retina. Brain Res 372:143-148.

Ascher P, Nowak L (1988a) Quisqualate- and kainate-activated channels in mouse central neurones in culture. J Physiol (Lond) 399:227245.

Ascher P, Nowak L (1988b) The role of divalent cations in the $\mathrm{N}$-methyl-d-aspartate responses of mouse central neurons in culture. J Physiol (Lond) 399:247-266.

Ascher P, Bregestovski P, Nowak L (1988) N-methyl-d-aspartate activated channels of mouse central neurones in magnesium-free solutions. J Physiol (Lond) 399:207-226.

Cull-Candy SG, Usowicz MM (1987) Mutiple-conductance channels activated by excitatory amino acids in cerebellar neurons. Nature 325 : $525-528$.

Cull-Candy SG, Howe JR, Ogden DC (1988) Noise and single channels activated by excitatory amino acids in rat cerebellar granule neurones. J Physiol (Lond) 400:189-222.

Dowling JE (1987) The retina: an approachable part of the brain. Cambridge, MA: Belknap.

Dowling JE, Pak MW, Lasater EM (1985) White perch horizontal cells in culture: methods, morphology and process growth. Brain Res 360: $331-338$.

Hals G, Christensen BN, O’Dell T, Christensen M, Shingai R (1986) Voltage-clamp analysis of currents produced by glutamate and some glutamate analogues on horizontal cells isolated from the catfish retina. J Neurophysiol 56:19-31.

IIamill OP, Marty A, Neher E, Sakmann B, Sigworth FJ (1981) Improved patch-clamp techniques for high-resolution current recording from cells and cell-free membrane patches. Eur J Physiol 391:85100.

Ishida AT, Neyton J (1985) Quisqualate and l-glutamate inhibit retinal horizontal-cell responses to kainate. Proc Natl Acad Sci USA 82: 1837-1841.

Ishida AT, Kaneko A, Tachibana M (1984) Responses of solitary retinal horizontal cells from Carassius auratus to L-glutamate and related amino acids. J Physiol (Lond) 348:255-270.

Jahr CE, Stevens CF (1987) Glutamate activates multiple single channel conductances in hippocampal neurons. Nature 325:522-525. 
Lasater EM, Dowling JE (1982) Carp horizontal cells in culture respond selectively to L-glutamate and its agonists. Proc Natl Acad Sci USA 79:936-940.

Lasater EM, Dowling JE, Ripps H (1984) Pharmacological properties of isolated horizontal and bipolar cells from the skate retina. J Neurosci 4:1966-1975.

Llano I, Marty A, Johnson JW, Ascher P, Gahwiler BH (1988) Patchclamp recording of amino acid-activated responses in "organotypic" slice cultures. Proc Natl Acad Sci USA 85:3221-3225.

Marc RE, Lam DMK (1981) Uptake of aspartic and glutamic acid by photoreceptors in goldfish retina. Proc Natl Acad Sci USA 78:71857189.

Mayer ML, Westbrook GL (1987) The physiology of excitatory amino acids in the vertebrate central nervous system. Prog Neurobiol 28: 197-276.

Murakami M, Ohtsu K, Ohtsuka T (1972) Effects of chemicals on receptors and horizontal cells in the retina. J Physiol (Lond) 227:899 913.
Nawy S, Copenhagen DR (1987) Multiple classes of glutamate receptor on depolarizing bipolar cells in retina. Nature 325:56-58.

Nowak L, Bregestovski P, Ascher P, Herbet A, Prochiantz A (1984) Magnesium gates glutamate-activated channels in mouse central neurons. Nature 307:462-465.

O'Dell TJ, Christensen BN (1989) Horizontal cells isolated from catfish retina contain two types of excitatory amino acid receptors. $J$ Neurophysiol 61:1097-1109.

Rowe JS, Ruddock KH (1982) Depolarization of retinal horizontal cells by excitatory amino acid neurotransmitter agonists. Neurosci Lett 30:257-262.

Slaughter MM, Miller RF (1981) 2-Amino-4-phosphonobutyric acid: a new pharmacological tool for retina research. Science 211:182-184.

Trussell LO, Fischbach GD (1989) Glutamate receptor desensitization and its role in synaptic transmission. Neuron 3:209-218.

Wu SM, Dowling JE (1978) L-Aspartate: evidence for a role in cone photoreceptor synaptic transmission in the carp retina. Proc Natl Acad Sci USA 75:5205-5209. 